\title{
ANALISIS CLUSTER DENGAN MENGGUNAKAN METODE K-MEANS UNTUK PENGELOMPOKKAN KABUPATEN/KOTA DI PROVINSI MALUKU BERDASARKAN INDIKATOR INDEKS PEMBANGUNAN MANUSIA TAHUN 2014
}

\author{
M. W. Talakua ${ }^{1}$, Z. A. Leleury ${ }^{2}$, A. W. Talluta ${ }^{3}$ \\ 1,2,3 Jurusan Matematika Fakultas Matematika dan Ilmu Pengetahuan Alam,Universitas Pattimura \\ Jalan Ir. M. Putuhena, Kampus Unpatti, Poka, Ambon, Indonesia \\ e-mail: ${ }^{1}$ ocat_14@yahoo.com; ${ }^{3}$ wandatalluta@yahoo.co.id
}

\begin{abstract}
Abstrak
Pembangunan manusia merupakan suatu tujuan utama untuk mengukur keberhasilan sebuah negara. Salah satu aspek penting untuk mengukur tingkat pembangunan manusia adalah masyarakat yang unggul dari segi kuantitas dan kualitas, maka dilihat dari tiga dimensi kehidupan yaitu peluang hidup, pengetahuan, dan kehidupan yang layak. Penelitian ini membahas tentang pemanfaatan algoritma $k$ means untuk mengelompokkan kabupaten/kota di Provinsi Maluku berdasarkan kemiripan karakteristik daerah yang ditinjau dari lima ukuran Indeks Pembangungan Manusia (IPM). Lima ukuran tersebut adalah Angka Harapan Hidup (AHH), Angka Melek Huruf (AMH), Rata-rata Lama Sekolah (RLS), dan Pengeluaran Per Kapita (PPK). Terdapat tiga cluster berdasarkan IPM yaitu: cluster 1: Kota Ambon, yang mempunyai angka IPM sangat maksimal. Cluster 2: MTB, Kepulauan Aru, SBB, SBT, MBD, dan Bursel, yang mempunyai angka IPM, AHH, AMH, RLS, dan PPK. Cluster 3: Malra, Malteng, Buru, Tual mempunyai angka IPM. AHH, AMH, RLS dan angka PPK. Berdasarkan angka Indeks Pembangunan Manusia, Angka Harapan Hidup, Angka Melek Huruf, Angka Rata-rata Lama Sekolah dan angka Pengeluaran Per Kapita, disimpulkan bahwa terdapat perbedaan yang signifikan pada tahun 2014.
\end{abstract}

Kata Kunci: analisis klaster, indeks pembangunan manusia, $k$-means cluster.

\section{CLUSTER ANALYSIS BY USING K-MEANS METHOD FOR GROUPING OF DISTRICT/CITY IN MALUKU PROVINCE INDUSTRIAL BASED ON INDICATORS OF MALUKU DEVELOPMENT INDEX IN 2014}

\begin{abstract}
Human development is a major goal to measure the success of a country. One important aspect to measure the level of human development is a society that is superior in terms of quantity and quality, it is seen from three dimension life that is the opportunity of life, knowledge, and a decent life. In this study discusses the utilization of k-means algorithm to cluster or grouping district or city in Maluku province. Based on the similarity of the regional characteristics in the review of the limits of the indicator size of IPM mortality of the area, namely Life Expectancy, Literacy Rate, Average School Attendance, and Income Per Capita. The purpose of this study is how to categorize and also to know whether there is a real difference between that groups. The data obtained from the central statistical agency then the results obtained from the five variables in telita there are three groups and also there are some differences found according to the characteristic of each variable. From this research, it becomes an input for the Maluku provincial government to be able to pay attention to all kinds of problems about IPM in this case the mortality of AHH, AMH, RLS and PPP. Based on human development index number, live expectancy, litercy rate, mean sof school duration and expendituri rate per capita, it can be conluded that there are significant differences in 2014
\end{abstract}

Keywords: Human Development Index, Cluster Analysis, K-Means Cluster 


\section{Pendahuluan}

Pembangunan nasional Indonesia menempatkan rakyat sebagai titik sentral pembangunan. Untuk dapat ikut berpartisipasi dalam proses pembangunan, tentunya dibutuhkan masyarakat yang unggul dari segi kuantitas dan kualitas. Oleh karena itu, dirumuskan suatu konsep baru dalam mengukur pembangunan yang berorientasi pada manusia [1]. Indeks Pembangunan Manusia (IPM) merupakan pengukur perbandingan keberhasilan pembangunan manusia yang mencakup tiga dimensi kehidupan manusia. Diantaranya peluang hidup (diukur dengan indikator hidup yang sehat dan panjang umur yang diukur dengan harapan hidup saat kelahiran dalam tahun), pengetahuan (diukur dengan indikator angka tingkat baca tulis dan rata-rata lama sekolah dalam tahun), dan hidup layak (diukur dengan indikator logaritma natural dari produk domestik bruto per kapita dalam partisipasi daya beli per bulan dalam ribuan rupiah). Setiap tahun daftar negara menurut IPM diumumkan berdasarkan penilaian tersebut. Pengukuran alternatif lain adalah Indeks Kemiskinan Manusia yang lebih berfokus pada kemiskinan.

Pengelompokan wilayah kabupaten/kota di Maluku perlu dilakukan sebagai bahan perencanaan dan evaluasi sasaran program pemerintah. Tujuannya untuk meningkatkan angka pembangunan manusia berdasarkan indikator pembentuk IPM. Oleh karena itu, digunakan salah satu analisis statistik yaitu analisis cluster dengan metode C-Means. Analisa dilakukan dengan mengelompokan kabupaten/kota di Provinsi Maluku berdasarkan indikator IPM. Indikator-indikator yang ada dinyatakan sebagai variabel dan IPM kabupaten/kota di Maluku dinyatakan sebagai objek yang dikelompokan berdasarkan kemiripan karakteristiknya. Setiap objek lain berada dalam cluster yang sama.

Selain itu, salah satu alogaritma data minim yang cukup populer digunakan baik dalam dunia bisnis, akademik, ataupun industri adalah Alogaritma K-Means. Alogaritma ini bekerja dengan cara membagi data dalam sejumlah cluster untuk dianalisis faktor kesamaan (similarity) maupun ketidaksamaan (dissimilarity) yang melekat pada kumpulan data tersebut. Kemudian dianalisis pola keterhubungan antar data.

Pada penelitian ini dibahas tentang pemanfaatan alogaritma K-Means untuk mengelompokan kabupaten/kota di Provinsi Maluku berdasarkan kemiripan karakteristik daerah yang ditinjau dari empat ukuran indikator mortalitas IPM di daerah. Ukuran indikator tersebut adalah Angka Harapan Hidup (AHH), Angka Melek Huruf (AMH), Rata-rata Lama Sekolah (RLS), dan Pengeluaran Per Kapita (PPK). Secara umum, output penelitian berupa hasil klasterisasi dapat digunakan sebagai sebuah acuan untuk menggambarkan distribusi pengelompokan berdasarkan kondisi profil IPM di Maluku.

\section{Metodologi Penelitian}

\subsection{Analisis Multivariat}

Analisis multivariat merupakan salah satu jenis analisis statistik yang digunakan untuk menganalisa data dengan banyak peubah bebas dan peubah terikat. Secara umum analisis multivariat di bagi menjadi dua metode, yaitu: metode dependen (dependent method) dan metode independen (independent method). Metode dependen digunakan untuk menganalisis ketergantungan di gunakan untuk menjelaskan atau memprediksi variabel terikat berdasarkan dua atau lebih variabel bebas. Sedangkan metode independen ini digunakan untuk menjelaskan seperangkat variabel untuk pengelompokan berdasarkan variabe-variabel tertentu. Metode ini dikelompokkan menjadi tiga, yaitu analisis faktor, analisis cluster, dan skala multidimensional.

Menurut Fadhli (2011), data dalam analisis multivariat dapat dinyatakan dalam bentuk matriks dengan $n$ baris (objek) dan $p$ kolom (variabel). Misalnya dalam suatu pengamatan terdapat $p$ variabel, dari banyaknya $n$ objek, maka data tersebut dapat di sajikan dalam bentuk matriks seperti berikut.

$$
X=\left[\begin{array}{cccc}
X_{11} & X_{12} & \cdots & X_{1 i} \\
X_{21} & X_{22} & \cdots & X_{2 i} \\
\vdots & \vdots & \ddots & \vdots \\
X_{n 1} & X_{n 2} & \cdots & X_{n 1}
\end{array}\right]
$$




\subsection{Analisis Cluster}

Clutering adalah proses membuat pengelompokan sehingga semua anggota dari setiap partisi mempunyai persamaan berdasarkan matriks tertentu. Analisis cluster atau analisis kelompok merupakan teknik analisa data yang bertujuan untuk mengelompokan individu atau objek ke dalam beberapa kelompok yang memiliki sifat berbeda antar kelompok, sehingga individu atau objek yang terletak di dalam satu kelompok akan mempunyai sifat relatif homogen. Tujuan analisis cluster adalah mengelompokan objekobjek tersebut.

Analisis Cluster memiliki beberapa kelebihan dan juga kekurangan sebagai berikut:

1) Kelebihan

a. Dapat mengelompokan data observasi dalam jumlah besar dan variabel yang relatif banyak. Data yang di reduksi dengan kelompok akan mudah dianalisis.

b. Dapat dipakai dalam skala data ordinal, interval dan rasio.

2) Kelemahan

a. Pengelompokan bersifat subjektifitas peneliti karena hanya melihat dari gambar dendogram.

b. Untuk data heterogen antara objek penelitian yang satu dengan yang lain akan sulit bagi peneliti untuk menentukan jumlah kelompok yang di bentuk.

c. Metode-metode yang dipakai memberikan perbedaan yang signifikan, sehingga dalam perhitungan biasanya masing-masing metode dibandingkan.

d. Semakin besar observasi, biasanya tingkat kesalahan akan semakin besar.

\subsection{Proses Analisis Cluster}

1) Menetapkan ukuran jarak antar data.

Mengukur kesamaan antara objek. Sesuai prinsip dasar cluster yang mengeelompokan objek yang mempunyai kemiripan, maka proses pertama adalah mengukur seberapa jauh ada kesamaan objek. Pengukuran jarak yang populer adalah metode Euclidean distance. Pada dasarnya, cara ini akan memasukan sebuah data ke dalam cluster tertentu dengan mengukur jarak data tersebut ke pusat cluster.

2) Melakukan proses standarisasi data jika diperlukan.

3) Melakukan pengklasteran.

Proses inti clustering adalah pengelompokan data, yang biasa dilakukan dengan dua metode yaitu:

a) Metode Hierarki

Metode ini memulai pengelompokan dengan dua atau lebih objek yang mempunyi kesaman paling dekat. Kemudian proses diteruskan ke objek lain yang mempunyai kedekatan kedua. Demikian seterusnya sehingga cluster akan membentuk semacam pohon dimana ada hierarki (tingkatan yang jelas) antara objek. Dendogram biasanya digunakan untuk membantu memperjelas proses hierarki tersebut.

b) Metode Nonhierarki

Berbeda dengan metode hierarki, metode ini justru di mulai dengan menentukan terlebih dahulu jumlah cluster yang diinginkan. Setelah jumlah cluster diketahui, baru proses cluster dilakukan tanpa mengikuti proses hierarki. Metode ini juga disebut K-Means cluster.

4) Melakukan penanaman cluster-cluster yang terbentuk.

5) Melakukan validasi dan profiling cluster.

Adapun ciri-ciri cluster adalah homogenitas (kesamaan) yang tinggi antara anggota dalam satu cluster (within cluster) dan heterogenitas (perbedaan) yang tinggi antara cluster yang satu dengan cluster lain (between-cluster). Analisis cluster memiliki beberapa istilah penting, antara lain:

1) Distances between cluster centers, yaitu jarak yang menunjukan bagaimana terpisahnya pasangan individu cluster.

2) Keanggotaan cluster (cluster membership), ialah keanggotaan yang menunjukan cluster untuk setiap objek yang menjadi anngotanya

3) Pusat cluster (cluster centers), ialah titik awal di mulai pengelompokan dalam cluster nonhierarki. 
4) Rata-rata lama cluster (cluster centroid), ialah nilai rata-rata variabel dari semua objek atau observasi dalam cluster tertentu.

5) Skedul aglomerasi (agglomeration schedule), ialah jadwal yang memberikan informasi tentang objek atau kasus yang dikelompokan pada setiap tahap pada suatu proses analisis cluster yang hierarki.

\subsection{Metode $C$-Means}

C-Means merupakan salah satu metode data clustering nonhierarki yang berusaha mempartisi data yang ada dalam bentuk satu atau lebih cluster, sehingga data dengan karakteristik yang sama dikelompokan dalam satu cluster yang sama pula. Data dengan karakteristik yang berbeda dikelompokan dalam kelompok yang lain. Metode yang termasuk dalam algoritma clustering berbasis jarak yang membagi data kedalam sejumlah cluster dan algoritma ini hanya bekerja pada atribut numerik.

C-Means merupakan salah satu algoritma dalam data mining yang biasa digunakan untuk melakukan clustering suatu data. Ada banyak pendekatan untuk membuat cluster, diantaranya adalah membuat aturan yang mendikte keanggotaan dalam kelompok yang sama berdasarkan tingkat persamaan di antara anggotaanggotanya. Pendekatan lainnya adalah dengan membuat sekumpulan fungsi yang mengukur beberapa properti dari pengelompokan tersebut sebagai fungsi dari beberapa parameter dari sebuah clustering. Mengelompokan data dengan metode C-Means dilakukan dengan algoritma sebagai berikut.

1) Tentukan jumlah kelompok.

2) Alokasikan data ke dalam kelompok secara acak.

3) Hitung pusat kelompok dari data yang ada di masing-masing kelompok. Lokasi centroid setiap kelompok diambil dari rata-rata semua nilai data dari setiap fiturnya. Jika $M$ menyatakan jumlah data dalam sebuah kelompok, $i$ menyatakan fitur ke-i dalam sebuah kelompok, dan $p$ menyatakan dimensi data, maka persamaan untuk menghitung centroid fitur ke-i digunakan persamaan (1).

$$
C^{1}=\frac{1}{M} \sum_{j=1}^{M} X_{j}
$$

Persamaan (1) dilakukan sebanyak $p$ dimensi dari $i=1$ sampai dengan $i=p$.

4) Alokasikan masing-masing data ke centroid/rata-rata terdekat. Ada beberapa cara yang dapat dilakukan untuk mengukur jarak data ke pusat kelompok, diantaranya adalah Euclidean pengukuran jarak pada ruang jarak (distance space). Euclidean dapat dicari menggunakan persamaan 2.

$$
d=\sqrt{\left(x_{1}-x_{2}\right)^{2}+\left(y_{1}-y_{2}\right)^{2}}
$$

Pengalokasian kembali data ke dalam masing-masing kelompok dalam metode K-Means didasarkan pada perbandingan jarak antara data dengan centroid setiap kelompok yang ada. Data dialokasikan ulang secara tegas ke kelompok yang mempunyai cetroid dengan jarak terdekat dari data tersebut. Pengalokasian data ini menurut MacQueen (1967) dapat ditentukan menggunakan persamaan (3).

$$
a_{i 1}= \begin{cases}1, & d=\min \left\{D\left(X_{i}, C_{l}\right)\right\} \\ 0, & \text { lainnya }\end{cases}
$$

$a_{i 1}$ adalah nilai keanggotaan titik $x_{i}$ ke pusat kelompok $C_{l}$, $d$ adalah jarak terpendek dari data $x_{i}$ ke $K$ kelompok setelah dibandingkan, dan $C_{l}$ adalah centroid ke-1. Fungsi objektif yang digunakan untuk metode K-Means ditentukan berdasarkan jarak dan nilai keanggotaan data dalam kelompok. Fungsi objektif menurut MacQueen (1967) dapat ditentukan menggunakan persamaan (4).

$$
J=\sum_{i=0}^{n} \sum_{i=1}^{k} a_{i c} D\left(x_{i}, c_{1}\right)^{2}
$$

dengan $n$ adalah jumlah data, $k$ adalah jumlah kelompok, $a_{i 1}$ adalah nilai keanggotaan titik data $x_{i}$ ke kelompok $c_{1}$ yang diikuti. $a$ mempunyai nilai 0 atau 1 . Apabila data merupakan anggota suatu kelompok, nilai $a_{i 1}=1$. Jika tidak, nilai $a_{i 1}=0$. Kembali ke langkah 3, apabila masih ada data yang berpindah kelompok atau apabila ada perubahan nilai centroid di atas nilai ambang yang ditentukan, atau apabila perubahan nilai pada fungsi objektif yang digunakan masih di atas nilai ambang yang ditentukan. 


\subsection{Konsep Pembangunan Manusia}

Manusia adalah kekayaan bangsa yang sesungguhnya. Tujuan utama dari pembangunan adalah menciptakan lingkungan memungkinkan bagi rakyatnya untuk menikmati umur panjang, sehat dan menjalankan kehidupan yang produktif. Hal ini tampaknya merupakan suatu kenyataan yang sederhana, akan tetapi sering terlupakan oleh berbagai kesibukan jangka pendek untuk mengumpulkan harta dan uang. Dalam [2], pembangunan manusia adalah suatu proses untuk memperbanyak pilihan pilihan yang dimiliki manusia. Diantara banyak pilihan pilihan tersebut, pilihan terpenting adalah untuk berumur panjang dan sehat, untuk berilmu pengetahuan, dan untuk mempunyai akses terhadap sumber daya yang di butuhkan agar dapat hidup layak.

Pembangunan manusia adalah pembangunan yang berpusat pada manusia, yang menempatkan manusia sebagai tujuan akhir dan bukan hanya sebagai alat pembangunan. Konsep pembangunan manusia yang di rekomendasikan oleh UNDP mencakup 4 indikator, yaitu kesejahteraan, produktifitas, pemberdayaan, dan berkelanjutan [1].

\subsection{Indeks Pembangunan Manusia}

Indeks Pembangunan Manusia (IPM) adalah pengukuran perbandingan dari harapan hidup, pendidikan dan standar hidup untuk semua negara diseluruh dunia. IPM digunakan untuk mengklasifikasikan apakah sebuah negara adalah negara maju, negara berkembang atau negara terbelakang, dan juga untuk mengukur pengaruh dari kebijakan ekonomi terhadap kualitas hidup. IPM mengukur pencapaian rata-rata sebuah negara dalam tiga dimensi dasar pembangunan manusia yaitu:

1) Hidup yang sehat dan panjang umur yang diukur dengan harapan hidup saat kelahiran.

2) Pengetahuan yang diukur dengan angka tingkat baca tulis dan rata-rata lama sekolah.

3) Standar kehidupan yang layak diukur dengan logaritma natural dari produk domestik bruto per kapita dalam paritasi daya beli.

Terdapat empat indikator Indeks Pembangunan Manusia, yaitu (BPS 2012)

1) Angka Harapan Hidup

Angka Harapan Hidup (AHH) merupakan rata-rata perkiraan banyak tahun yang dapat ditempuh seseorang selama hidupnya. Perhitungan AHH melalui pendekatan tak langsung (indirect estimation). Jenis data yang digunakan adalah Anak Lahir hidup dan Anak Masih Hidup. Indeks harapan hidup dihitung dengan menghitung nilai maksimum dan nilai minimum harapan hidup sesuai standar UNDP, yaitu angka tertinggi sebagai batas atas untuk menghitung indeks dipakai 85 tahun dan terendah adalah 20 tahun.

2) Angka Melek Huruf

Angka Melek Huruf (AMH) adalah persentase penduduk usia 15 tahun ke atas yang bisa membaca dan menulis.

3) Rata-rata Lama Sekolah (RLS).

Rata-rata Lama Sekolah ( RLS ) adalah lama sekolah (tahun) penduduk usia 15 tahun ke atas.

4) Kemampuan daya beli penduduk yaitu kemampuan masyarakat secara ekonomi dalam memenuhi kebutuhan konsumsinya.

\section{Hasil dan Pembahasan}

\subsection{Variabel Yang Digunakan}

Data yang digunakan adalah data sekunder dari hasil pendataan Badan Pusat Statistik (BPS) Provinsi Maluku. Dalam penilitian ini variabel-variabel yang digunakan adalah indikator IPM sebagai berikut.

$X_{1}$ : Persentase Angka IPM

$X_{2}:$ Persentase AHH

$X_{3}:$ Persentase AMH

$X_{4}$ : Persentase Angka RLS

$X_{5}$ : Persentase PPK. 


\subsection{Hasil Penelitian}

\subsubsection{Data indikator Indeks Pembangunan Manusia}

Data yang digunakan dalam penelitian ini adalah data dari BPS tahun 2014, yakni IPM $\left(X_{1}\right)$, AHH $\left(X_{2}\right)$, AMH $\left(X_{3}\right)$, RLS $\left(X_{4}\right)$, dan PPK $\left(X_{5}\right)$.

Tabel 1. Data Derajat Indikator IPM

\begin{tabular}{|c|l|c|c|c|c|c|}
\hline No & Kabupaten/Kota & IPM & AHH & AMH & RLS & PPK \\
\hline 1 & Maluku Tenggara Barat & 59,81 & 62,50 & 11,81 & 8,88 & 5.600 \\
\hline 2 & Maluku Tenggara & 62,74 & 63,98 & 12,06 & 8,71 & 6.804 \\
\hline 3 & Maluku Tengah & 68,69 & 65,59 & 13,55 & 8,88 & 9.547 \\
\hline 4 & Buru & 65,15 & 65,50 & 12,23 & 7,15 & 9.420 \\
\hline 5 & Kep. Aru & 59,91 & 61,57 & 11,03 & 7,98 & 6.891 \\
\hline 6 & Seram Bagian Barat & 62,39 & 59,90 & 12,70 & 8,42 & 7.779 \\
\hline 7 & Seram Bagian Timur & 59,50 & 57,70 & 11,71 & 6,97 & 8.492 \\
\hline 8 & MBD & 58,09 & 60,63 & 11,30 & 7,60 & 6.150 \\
\hline 9 & Buru selatan & 60,74 & 65,36 & 11,69 & 6,62 & 6.915 \\
\hline 10 & Ambon & 79,09 & 69,46 & 15,88 & 11,61 & 13.146 \\
\hline 11 & Tual & 64,95 & 63,76 & 13,84 & 9,65 & 6.642 \\
\hline
\end{tabular}

Data yang telah diperoleh dari BPS Provinsi Maluku, selanjutnya diproses menggunakan SPSS.16 untuk membentuk cluster berdasarkan indikator IPM di Provinsi Maluku dengan menggunakan metode nonhierarki.

\subsubsection{Proses Pengelompokkan Dengan Metode Non Hierarki}

Pada statistik deskriptif dibawah ini menunjukan bahwa semua data lengkap yaitu angka IPM, AHH, AMH, angka RLS, dan angka PPK pada 11 kabupaten/kota di Provinsi Maluku.

Tabel 2. Statistik Deskriptif

\begin{tabular}{|l|r|r|r|r|r|}
\hline & \multicolumn{1}{|c|}{ IPM } & AHH & AMH & \multicolumn{1}{c|}{ RLS } & \multicolumn{1}{c|}{ PPP } \\
\hline$N$ & 11 & 11 & 11 & 11 & 11 \\
\hline Minumum & 58 & 57 & 11 & 6 & 5 \\
\hline Maximum & 79 & 69 & 15 & 11 & 13 \\
\hline Means & 63,18 & 62,64 & 12,00 & 7,73 & 7,44 \\
\hline Std.Deviation & 6.080 & 3.355 & 1.265 & 1.421 & 2.255 \\
\hline
\end{tabular}

\subsubsection{Data Quick Cluster}

Tabel 3. Hasil Output Data Quick Cluster SPSS.16

\begin{tabular}{|c|c|c|c|}
\hline \multirow{2}{*}{} & \multicolumn{3}{|c|}{ Initial Cluster Centers } \\
\cline { 2 - 4 } & $\mathbf{1}$ & $\mathbf{2}$ & $\mathbf{3}$ \\
\cline { 2 - 4 } & 2,60177 & $-0,68782$ & 0,79249 \\
\hline IPM & 1,89689 & $-1,68010$ & 0,70456 \\
\hline AHH & 2,31717 & $-0,79057$ & 0,79057 \\
\hline AMH & 2,30372 & $-1,21585$ & 0,19198 \\
\hline RLS & 2,46389 & 0,24631 & 0,68983 \\
\hline PPP & \multicolumn{3}{c}{} \\
\hline
\end{tabular}

Output ini adalah tampilan pertama proses clustering data sebelum melakukan iterasi. Karena nanti akan dihasilkan proses clustering sesudah iterasi yang justru adalah hasil akhir cluster, maka output ini tidak akan dianalisis.

\subsubsection{Proses Iterasi}

Dari hasil output SPSS.16, dapat diketahui bahwa proses iterasi dilakukan sebanyak 3 kali. Proses ini dilakukan untuk mendapatkan cluster yang tepat dalam mengelompokkan 11 kabupaten/kota. Jarak minimum antar pusat cluster yang terjadi dari nilai minimum adalah 3,544. 
Tabel 4. Final Cluster Centers

\begin{tabular}{|c|c|c|c|}
\hline & \multicolumn{3}{|c|}{ Final Cluster } \\
\cline { 2 - 4 } & $\mathbf{1}$ & $\mathbf{2}$ & $\mathbf{3}$ \\
\hline IPM & 2,60177 & $-0,60558$ & 0,25793 \\
\hline AHH & 1,89689 & $-0,58713$ & 0,40648 \\
\hline AMH & 2,31717 & $-0,65881$ & 0,39528 \\
\hline RLS & 2,30372 & $-0,51194$ & 0,19198 \\
\hline PPP & 2,46389 & $-0,42702$ & 0,02455 \\
\hline
\end{tabular}

Berdasarkan output di Tabel 4, dapat diketahui bahwa data tersebut masih terkait dengan proses standarisasi yang mengacu pada z-score dengan ketentuan sebagai berikut.

1) Angka negatif (-) berarti data dibawa rata-rata total.

2) Angka positif ( + ) berati diatas rata-rata total.

\subsubsection{Tafsiran Setiap Cluster}

Berdasarkan Tabel 3 dengan ketentuan yang telah dijelaskan, dapat didefenisikan sebagai berikut.

Cluster 1: Pada cluster 1 diperoleh bahwa pada tahun 2014 angka RLS, angka PPK dan angka IPM dan AHH di atas rata-rata pada 11 kabupaten/kota di Provinsi Maluku. Angka RLS sangat minim. AMH dan angka PPK biasa dikatakan bahwa masih sedang diatas rata-rata. Sedangkan angka IPM dan AHH sangat banyak terjadi pada tahun 2014.

Cluster 2: Pada cluster 2 diperoleh bahwa pada tahun 2014, angka RLS dan PPK di bawah rata-rata. AMH dapat dikatakan bahwa masih sedang dibandingkan dengan RLS dan PPK pada 11 kabupaten/ kota di Provinsi Maluku. Dari ciri-ciri tersebut dapat dikatakan bahwa angka RLS dan angka PPK sangat rendah terjadi pada tahun 2014.

Cluster 3: Pada cluster 3 diperoleh bahwa pada tahun 2014, AHH dan angka IPM di atas rata-rata sedangkan AMH masih sedang dibandingkan dengan angka RLS dan angka PPK di bawah ratarata. Dari ciri tersebut,dapat dikatakan bahwa untuk angka PPK dan RLS sangat rendah terjadi pada tahun 2014.

Setelah membentuk 3 cluster, langkah selanjutnya adalah melihat apakah variabel-variabel yang telah terbentuk cluster mempunyai perbedaan pada setiap cluster. Dalam hal ini dapat dilihat dari $F$ dan nilai probalitas (sig) masing-masing variabel. Hal ini di lakukan dengan melihat ouput Anova berikut.

Tabel 5. Anova

\begin{tabular}{|l|r|r|r|r|r|r|}
\hline \multicolumn{7}{|c|}{ ANOVA } \\
\cline { 2 - 5 } & \multicolumn{2}{|c|}{ Cluster } & \multicolumn{2}{c|}{ Error } & & \\
\cline { 2 - 7 } & Mean Square & df & Mean Square & df & \multicolumn{1}{c|}{ F } & Siq. \\
\hline Zscore(IPM) & 4.618 & 2 & .096 & 8 & 48.338 & .000 \\
Zscore(AHH) & 3.164 & 2 & .459 & 8 & 6.891 & .018 \\
Zscore(AMH) & 4.427 & 2 & .143 & 8 & 30.909 & .000 \\
Zscore(RLS) & 3.514 & 2 & .372 & 8 & 9.455 & .008 \\
Zscore(PPP) & 3.584 & 2 & .354 & 8 & 10.121 & .006 \\
\hline
\end{tabular}

The $\mathrm{F}$ tests should be used only for descriptive purposes because the clusters have been chosen to maximize the differences among cases in different clusters. The observed significance levels are not corrected for this and thus cannot be interpreted as tests of the hypothesis that the cluster means are equal.

Pada Tabel 5 dapat dilihat bahwa kolom cluster menunjukan besaran between Cluster means, sedangkan kolom error menunjukan besaran within Cluster means sehingga nilai F diperoleh dari:

Sebagai contoh:

$$
F=\frac{\text { between means }}{\text { within meaans }}
$$

1. angka $F$ pada $Z$ IPM didapat dari:

$$
\begin{aligned}
& \mathrm{F}=\frac{\text { between means } Z \text { IPM }}{\text { within means } Z \text { IPM }} \\
& \mathrm{F}=\frac{\mathbf{4 , 6 1 8}}{\mathbf{0 , 0 9 6}}=48,338
\end{aligned}
$$

2. $\quad$ angka $\mathrm{F}=$ pada $Z$ AHH didapat dari:

$$
\begin{aligned}
& \mathrm{F}=\frac{\text { between means } Z \mathrm{AHH}}{\text { within means } Z \mathrm{AHH}} \\
& \mathrm{F}=\frac{3,164}{0,459}=6,891
\end{aligned}
$$


3. angka F pada $Z$ AMH didapat dari:

$$
\begin{aligned}
& \mathrm{F}=\frac{\text { between means } Z A M H}{\text { within means } Z A M H} \\
& \mathrm{~F}=\frac{\mathbf{4 , 4 2 7}}{0,143}=30,909
\end{aligned}
$$

5. angka F pada Z PPP didapat dari:

$\mathrm{F}=\frac{\text { between means } Z P P P}{\text { within means } Z P P P}$

$$
\mathrm{F}=\frac{\mathbf{3 , 5 8 4}}{0,354}=10,121
$$

Interprestasi angka $\mathrm{F}$ adalah semakin besar angka $\mathrm{F}$ suatu variabel dan angka signifikansinya adalah 0,05, maka semakin besar pula perbedaan variabel tersebut pada ketiga variabel. Sebagai contoh, angka $\mathrm{F}$ terbesar $(48,338)$ ada pada Z IPM, dengan angka kolom SIG 0,000 yang berarti signifikansinya adalah nyata. Hal ini berarti faktor angka IPM sangat membedakan karakteristik ketiga cluster tersebut. Atau dapat dikatakan angka IPM pada ketiga cluster yang sangat berbeda antara cluster 1 dengan cluster lainya. Perhatikan variabel $Z$ AMH, yang mempunyai angka $F$ sebesar 30,909 dan sig 0,00 yang berarti signifikansinya juga adalah nyata. Perhatikan pula perbedaannya dengan variabel $Z$ AHH, yang mempunyai tingkat $\mathrm{F}$ sebesar 6,891 dan sig 0,18. Hal tersebut menyatakan bahwa signifikansinya di atas 0,05 ( 0,018 > 0,05 ). Maka variabel $Z$ AHH pada cluster 1, cluster 2 dan cluster 3 tetap mempunyai perbedaan. Walaupun demikian, angka F variabel $Z$ IPM lebih besar dari F variabel $Z$ AMH. Dengan demikian, angka IPM lebih banyak dari angka melek huruf pada ketiga cluster.

\subsubsection{Jumlah Anggota Setiap Cluster}

Tabel 6. Number Of Cases In Each Cluster

\begin{tabular}{|c|c|}
\hline Cluster & Jumlah Kab/Kota \\
\hline 1 & 1.000 \\
\hline 2 & 6.000 \\
\hline 3 & 4.000 \\
\hline
\end{tabular}

Pada Tabel 6, dapat dilihat bahwa data terbanyak ada pada cluster 2, yaitu 6 kabupaten/kota. Data sedang ada pada cluster 3, yaitu 4 kabupaten/kota. Sedangkan data paling sedikit ada pada cluster 1 yaitu 1 kabupaten/kota. Karena tidak ada variabel yang hilang (missing), dengan demikian semua data sejumlah 11 kabupaten lengkap terdata pada ke 3 cluster dengan komposisi seperti di atas karena cluster 2 merupakan cluster terbesar.

\subsubsection{Analisis Komposisi Cluster}

Tabel 7. Komposisi Cluster

\begin{tabular}{|l|c|c|}
\hline \multicolumn{1}{|c|}{ Kab/Kota } & Cluster & Distance \\
\hline MTB & 2 & 1,053 \\
\hline MALUKU TENGGARA & 3 & 0,945 \\
\hline MALUKU TENGAH & 3 & 0,987 \\
\hline BURU & 3 & 1,089 \\
\hline KEP. ARU & 2 & 0,259 \\
\hline SERAM BAGIAN BARAT & 2 & 1,182 \\
\hline SERAM BAGIAN TIMUR & 2 & 1,472 \\
\hline MBD & 2 & 0,404 \\
\hline BURU SELATAN & 2 & 1,495 \\
\hline AMBON & 1 & 0,000 \\
\hline TUAL & 3 & 1,095 \\
\hline
\end{tabular}

Contoh penafsiran:

a) Cluster 1: Kota Ambon mempunyai angka IPM dan AHH sangat maksimal (sangat banyak sedangkan jumlah AMH, angka RLS dan PPK berbanding balik dengan angka IPM yaitu terjadi pada tahun 2014.

b) Cluster 2: MTB, Kepulaan Aru, SBB, SBT, MBD, dan Buru Selatan mempunyai angka IPM, AHH, AMH, RLS, dan angka PPK sangat rendah terjadi pada tahun 2014. 
c) Cluster 3: Maluku Tenggara, Maluku Tengah, Buru, Tual mempunyai angka IPM, AHH, AMH, RLS, dan angka PPK sangat banyak terjadi pada tahun 2014.

\section{Kesimpulan}

Berdasarkan hasil dan pembahasan, maka dapat disimpulkan pengelompokan kabupaten/kota berdasarkan angka Indeks Pembangunan Manusia, Angka Harapan Hidup, Angka Melek Huruf, angka Ratarata Lama Sekolah, dan angka Pengeluaran per Kapita kurang terjadi pada tahun 2014. Terdapat 3 cluster atau 3 kelompok yaitu:

a) Cluster 1 yakni Kota Ambon dengan angka IPM sangat maksimal. Sedangkan jumlah AHH, AMH, RLS, dan angka PPK sangat banyak terjadi pada tahun 2014.

b) Cluster 2 yakni MTB, Kepulaan Aru, SBB, SBT, MBD, dan Buru Selatan mempunyai angka IPM AHH, AMH, RLS, dan PPK kurang terjadi pada tahun 2014.

c) Cluster 3 : Malra, Malteng, Buru, Tual, mempunyai angka IPM, AHH, AMH, RLS dan angka PPK banyak terjadi pada tahun 2014.

\section{Daftar Pustaka}

[1] Abdyo and H. Permadi, Metode Statistika Praktis, Malang: Universitas Negeri Malang, 1999.

[2] B. P. S. P. Maluku, “Indikator Indeks Pembangunan Manusia 2010-2014,” Badan Pusat Statistik Provinsi Maluku, Juli 2014. [Online]. Available: https://maluku.bps.go.id/subject/26/indeks-pembangunan-manusia.html. [Accessed Juli 2014].

[3] B. P. S. P. Maluku, “Indikator Kesejahteraan Rakyat Provinsi Maluku 2014,” Badan Pusat Statistik Provinsi Maluku, [Online]. Available: https://maluku.bps.go.id/publication/2015/09/30/6cc18acb861407726a19addc/ indikator-kesejahteraan-rakyat-provinsi-maluku-2014.html.

[4] Windha Mega P. D., “Clustering Menggunakan Metode K-Means Untuk Menentukan Status Gizi Balita,” Jurnal Informatika, vol. 15, no. No.2, pp. 160-174, 2015. 
